\title{
Correction to: The spectrum of cloacal malformations: how to differentiate each entity prenatally with fetal MRI
}

\author{
Kimberly A. Dannull ${ }^{1,2}$ (D) Lorna P. Browne ${ }^{1,2} \cdot$ Mariana L. Meyers ${ }^{1,2}$
}

Published online: 5 April 2019

(C) Springer-Verlag GmbH Germany, part of Springer Nature 2019

Correction to: Pediatric Radiology (2019) 49:387-398

https://doi.org/10.1007/s00247-018-4302-x

The published version of this article unfortunately contained a mistake. Author name Mariana Z. Meyers was incorrect. The correct middle initial is given above.

Publisher's note Springer Nature remains neutral with regard to jurisdictional claims in published maps and institutional affiliations.

The online version of the original article can be found at https://doi.org/ 10.1007/s00247-018-4302-x

Kimberly A. Dannull

kimberly.dannull@childrenscolorado.org

1 Department of Diagnostic Radiology,

Division of Pediatric Radiology,

Children's Hospital Colorado,

13123 East 16th Ave., Mailbox B-463,

Aurora, CO 80045, USA

2 Department of Radiology,

University of Colorado School of Medicine,

Anschutz Medical Campus, Aurora, CO, USA 